AperTO - Archivio Istituzionale Open Access dell'Università di Torino

\title{
EFFECT OF PREHARVEST AND POSTHARVEST APPLICATION OF CHITOSAN COATING ON STORAGE QUALITY OF NECTARINES
}

\section{This is the author's manuscript}

Original Citation:

Availability:

This version is available http://hdl.handle.net/2318/1532758

since 2015-12-11T14:11:08Z

Publisher:

ISHS

Terms of use:

Open Access

Anyone can freely access the full text of works made available as "Open Access". Works made available under a Creative Commons license can be used according to the terms and conditions of said license. Use of all other works requires consent of the right holder (author or publisher) if not exempted from copyright protection by the applicable law. 


\title{
Effect of preharvest and postharvest application of chitosan coating on storage quality of nectarines
}

\author{
Giovanna Giacalone, Valentina Chiabrando
}

Department of Agriculture, Forest and Food Science, Via L. da Vinci 44, Grugliasco (TO), Italy

Nectarine is a climacteric fruit and exhibits increased ethylene production, respiration rate, changes in fruit texture, colour, aroma and other biochemical and physiological attributes during fruits ripening. It has a limited storage life depending upon the cultivar. The coating of fruit with edible materials has been reported to act as a barrier to moisture and oxygen during postharvest handling and storage. Different compounds have been used as coating materials in fruits including alginate, cellulose, chitosan, chitin, lipids, milk protein, starch and wax with varying success towards extending shelf life and maintaining fruit quality. Chitosan coating had the potential to inhibit decay and hence prolong the storage life of a variety of produce including strawberries, tomatoes, citrus fruit, peaches, pears and kiwi fruit. In this study biodegradable coatings, based on chitosan, were applied to nectarine, cv Diamond Ray, in order to find environmentally friendly, healthy treatments with which better preserve fresh fruit quality and safety during postharvest cold storage. Physicochemical properties (weight loss, ${ }^{\circ}$ Brix, titratable acidity, colour and texture) were determined throughout cold storage. Four treatment were investigated: (1) preharvest chitosan $\left(10 \mathrm{~g} \mathrm{l}^{-1}\right)$ applications, (2) pre and postharvest chitosan (10 $\mathrm{g}$ $\left.\mathrm{l}^{-1}\right)$ applications, (3) postharvest chitosan $\left(10 \mathrm{~g} \mathrm{l}^{-1}\right)$ application (4) control, without application. Preharvest chitosan-treated nectarines were firmer and had higher soluble solids content than control ones. Also pre and postharvest application fruits showed high soluble solids content and texture values and the highest titratable acidity. Hence it can be concluded that chitosan in preharvest treatments has the potential to preserve valuable attributes and prolong the shelf-life of postharvest nectarines, presumably of its property to inhibit the ripening and senescence process of postharvest fruits.

Keywords: Diamond Ray, weight loss, titratable acidity, colour, texture.

\section{Introduction}

Postharvest quality losses in nectarines are caused predominantly by metabolic changes, mechanical damage, reduction in pulp firmness, physiological disorders and decay. Thus there is a need to develop methods for controlling postharvest decay of nectarine fruits. In trying to reduce these losses, authors have studied new genotypes (Manganaris et al., 2006) and have examined pre-harvest conditions, harvesting procedures, post-harvest treatments like coatings ( $\mathrm{Li}$ and Yu, 2000), cold storage (Girardi 
et al., 2005) and controlled atmosphere (Zhou et al., 2000). Edible coatings, a new strategy used to extend shelf-life and to improve food quality of whole fruits and fresh-cut fruits, have been applied to many products (Asgar et al., 2011). Coatings on products create a barrier to external elements that can reduce solutes migration, respiration, moisture loss and oxidative reaction rates (Barbosa et al., 2011, Cè et al., 2012, Duan et al., 2011). Chitosan has been one of the most promising coating materials for fruits. Chitosan is a biopolymer which has been the object of considerable interest for applications in agriculture, biomedicine, biotechnology, and food industry due to its biocompatibility, biodegradability, and bioactivity. Chitosan was reported to prolong storage life and control decay of several fruit (Bautista-Baños et al., 2006, Oberland et al., 2005). The objective of this study was to determine if a chitosan coating can control the decay and maintain the quality of nectarine fruit during postharvest storage.

\section{Material and methods}

Fruit material

Nectarine, cv Diamond Ray, were hand harvested at commercial picking. The nectarines were selected for uniformity, colour, absence of deformity or disease and size. Four treatments were considered:

1. Preharvest treatment

2. Postharvest treatment

3. Preharvest treatment and postharvest treatment

4. Without treatment (control)

\section{Preharvest treatments}

The trials were carried out in a commercial orchard located in the Cuneo Province in the north-west of Italy, an important fruit growing district in Piedmont Region. The trees were selected for uniformity of production and ripening. The canopy of Diamond Ray trees was sprayed with a solution of commercial chitosan (Chitoplant ${ }^{\circledR}$, Agritalia, Italy) $\left(10 \mathrm{gl}^{-1}\right)$. Spraying used a back pump (WJR2525, Honda, Japan) to deliver the equivalent volume of 1000 1/ha. Two treatments were made: 20 and 10 days before harvest. Untreated trees were used as controls. Commercial formulations of chitosan have the advantage of more practical use, as viscosity is lower than that of the biopolymer dissolved in acid solution.

\section{Postharvest treatments}

Film forming solution was prepared dissolving $10 \mathrm{gl}^{-1}$ of Chitoplant ${ }^{\circledR}$ (Agritalia, $^{\text {A }}$ Italy), a commercial chitosan formulation, in deionized water with continuous shaking until the solution became clear. No plasticizer was added, in according with Chiabrando and Giacalone (2013). The nectarines were randomized and immersed for $1 \mathrm{~min}$ in the tested solutions and and then allowed to drip off at room temperature. Nectarines immersed in deionized water were used as the control. Samples nectarines were than stored at $0^{\circ} \mathrm{C}$.

\section{Quality analysis}

After 1, 7, 14, 23 and 30 days of storage a sample of 15 nectariness was removed randomly from each treatment and analysed for weight loss, firmness, soluble solid content, titratable acidity and colour. Weight loss was determined by weighting each 
nectarine at 7 day intervals during storage. Values are reported as percent of weight loss per initial fruit weight.

Pulp firmness was determined using a hand penetrometer (TR Fruit Test 327, Italy) with an 8-mm tip, and results expressed in Newtons (N) (means of 30 values). For each fruit, two readings were taken in the equatorial region of the fruit after the skin was removed. The readings were taken on opposite sides of the fruit. Total soluble solids (TSS) content was determined in the juice of single fruit with a digital refractometer Atago PR-101 (Atago, Japan) at $20^{\circ} \mathrm{C}$ and results expressed as ${ }^{\circ}$ Brix (means of 15 fruits). Titratable acidity (TA) was determined by titration with $0.1 \mathrm{~N} \mathrm{NaOH}$ up to $\mathrm{pH} 8.1$, using $10 \mathrm{ml}$ of diluted juice in distilled $\mathrm{H}_{2} \mathrm{O}$ and results were expressed as meq/L. Skin colour analysis was performed at $1,7,14,23$ and 30 days of cold storage at $0^{\circ} \mathrm{C}$. $\mathrm{L}^{*}, \mathrm{a}^{*}$, and $\mathrm{b}^{*}$ values were determined at two points along each side of the nectarines using a Minolta chromameter (CR400; Minolta, Japan).

\section{Statistical analysis}

The experimental design was completely randomized with three replications. Data were analyzed by analysis of variance using statistical procedures of the STATISTICA ver. 6.0 (Statsoft Inc., Tulsa,OK,USA). The source of variance was the chitosan treatments. Tukey's test HSP (honestly significant differences) was used to determine significant differences among treatment means. Means values were considered significantly different at $\mathrm{P} \leq 0.05$.

\section{Results}

Chitosan application reduced the postharvest weight loss of nectarines when applied in preharvest, and pre plus postharvest compared to control and to postharvest treatments, wich showed the higher weight loss during storage. The effects were not statistically different from each other (Fig. 1).

Fig. 1. Evolution of weight loss (\%) during cold storage of nectarines.

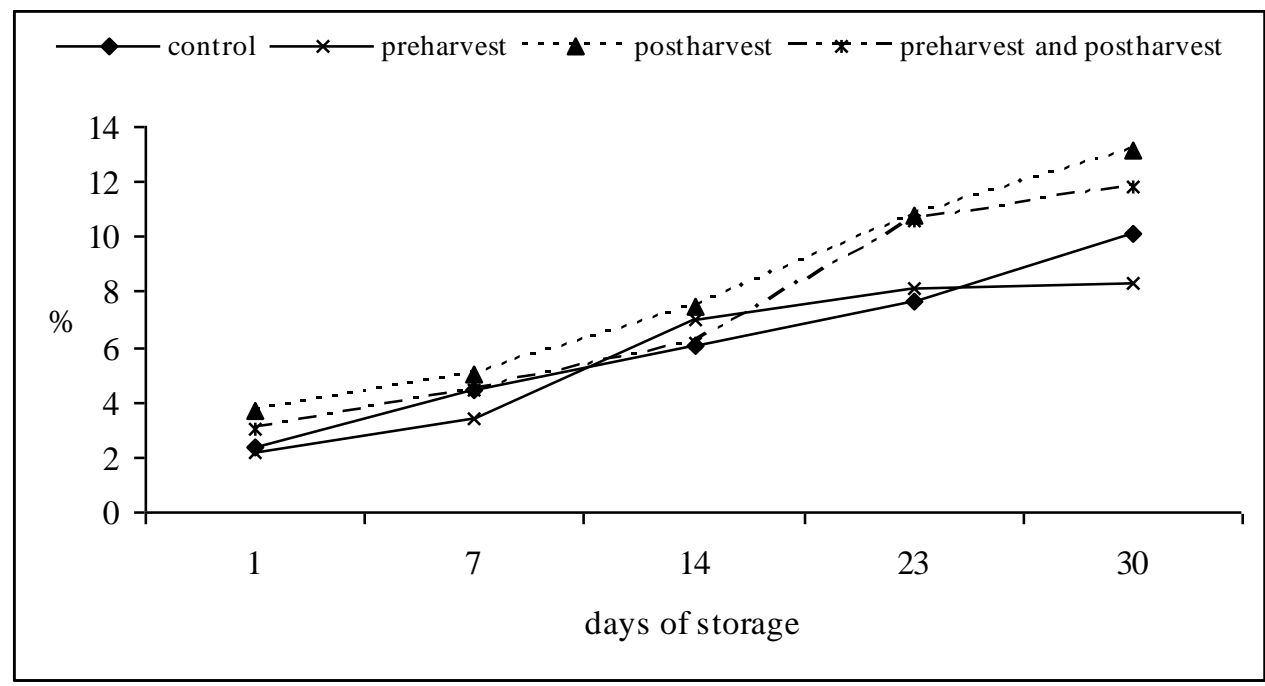


The concentrations of total soluble solids increased and titratable acidity and firmness decreased over time during postharvest storage (Tab. 1). In particular, preharvest application of chitosan was effective in reducing significantly firmness losses during postharvest storage, in according with Li and Yu (2000). For soluble solids content, chitosan treated nectarines showed the higher values during postharvest storage, compared to the control. The most effective treatment in controlling postharvest acidity losses of nectarines was chitosan application in pre plus postharvest treatment (Tab. 2). The faster decrease in acidity gave rise to a faster senescence (Asgar et al., 2011). The higher levels of total soluble solids and titratable acidity in the pulp of the nectarines coated with chitosan may be due to protective $\mathrm{O}_{2}$ barrier or reduction of oxygen supply on the fruit surface which inhibited respiration (Jiang and Li, 2000; Yonemoto et al., 2002). The impact of the chitosan on $\mathrm{O}_{2}$ and $\mathrm{CO}_{2}$ concentrations in relation to fruit respiration requires investigation. The levels of titratable acidity were correlated with the antibrowning efficacy of the treatments. Han et al. (2004) reported that in raspberry and strawberry, the chitosan coatings slowed down the changes in titratable acidity, effectively delaying fruit ripening. During storage, very little reduction in hue angle and lightness was observed in all the treatments (Table 2). Preharvest chitosan application showed the higher $\mathrm{L}$ values during storage, and also the higher $\mathrm{h}$ values at the end of storage period compared to control (Table 2). Thus, preharvest treatment with chitosan coating delayed the browning and lightness loss of necatrines skin colour. Similar results was also obtained in postharvest chitosan application. Samples fruits of this treatment showed, at the end of storage period, significant higher values of $\mathrm{L}$ and $\mathrm{h}$ compared to control, in according with Jiang et al.(2005). This result is probabily due because chitosan solutions have antioxidant capacity and the use of chitosan as an antioxidant and antibrowning agent is widespread in the food industry (Devlieghere et al., 2004).

Table 1. Quality parameters of nectarines during cold storage. Different letters indicates the value is statistically different from that corresponding to control $(\mathrm{P} \leq 0.05)$.

\begin{tabular}{llccccc}
\hline & & \multicolumn{5}{c}{ days of storage at $0^{\circ} \mathrm{C}$} \\
\hline parameter & treatments & 1 & 7 & 14 & 23 & 30 \\
\hline SSC $\left({ }^{\circ}\right.$ brix $)$ & & & & & \\
& control & $11.69 \mathrm{bc}$ & 12.02 & $11.89 \mathrm{~b}$ & $11.87 \mathrm{c}$ & $12.12 \mathrm{~b}$ \\
& preharvest application & $12.73 \mathrm{~b}$ & 12.46 & $12.94 \mathrm{a}$ & $12.94 \mathrm{~b}$ & $13.8 \mathrm{a}$ \\
& postharvest application & $12.23 \mathrm{~b}$ & 12.76 & $12.14 \mathrm{ab}$ & $12.77 \mathrm{~b}$ & $13.52 \mathrm{a}$ \\
& preharvest and postharvest application & $13.02 \mathrm{a}$ & 12.46 & $12.35 \mathrm{ab}$ & $13.63 \mathrm{a}$ & $13.51 \mathrm{a}$ \\
\hline & & & & & & \\
\hline texture (N) & control & 52.78 & $58.66 \mathrm{a}$ & 54.94 & 43.95 & $40.22 \mathrm{ab}$ \\
& preharvest application & 56.21 & $60.13 \mathrm{a}$ & 55.82 & 49.05 & $43.75 \mathrm{a}$ \\
& postharvest application & 55.13 & $54.83 \mathrm{~b}$ & 53.56 & 46.60 & $36.78 \mathrm{~b}$ \\
& preharvest and postharvest application & 55.23 & $54.54 \mathrm{~b}$ & 55.82 & 49.54 & $41.49 \mathrm{ab}$ \\
\hline & & & & & & $72.92 \mathrm{~b}$ \\
\hline & acidity (meq/l) & $112.55 \mathrm{~b}$ & $113.18 \mathrm{~b}$ & $95.69 \mathrm{c}$ & $79.13 \mathrm{~b}$ & $72.48 \mathrm{~b}$ \\
& & $127.7 \mathrm{a}$ & $89.57 \mathrm{~d}$ & $103.35 \mathrm{a}$ & $79.09 \mathrm{~b}$ & 71.48 \\
& prehtrol & $115.34 \mathrm{~b}$ & $126.28 \mathrm{a}$ & $97.18 \mathrm{~b}$ & $96.17 \mathrm{a}$ & $72.74 \mathrm{~b}$ \\
& postharvest application & $128.64 \mathrm{a}$ & $109.6 \mathrm{c}$ & $98.19 \mathrm{~b}$ & $94.84 \mathrm{a}$ & $76.9 \mathrm{a}$ \\
\hline
\end{tabular}


Table 2. Colour parameters of nectarines during cold storage. Different letters indicates the value is statistically different from that corresponding to control $(\mathrm{P} \leq 0.05)$.

\begin{tabular}{llccccc}
\hline & & \multicolumn{5}{c}{ days of storage at $0{ }^{\circ} \mathrm{C}$} \\
\hline parameter & treatments & 1 & 7 & 14 & 23 & 30 \\
\hline Lightness & & & & & & \\
\hline & control & $25.74 \mathrm{~b}$ & $26.14 \mathrm{~b}$ & $25.29 \mathrm{~b}$ & $26 \mathrm{a}$ & $26.11 \mathrm{ab}$ \\
& preharvest application & $28.01 \mathrm{a}$ & $27.01 \mathrm{a}$ & $26.25 \mathrm{a}$ & $24.42 \mathrm{~b}$ & $27.59 \mathrm{a}$ \\
& postharvest application & $26.08 \mathrm{~b}$ & $26.57 \mathrm{~b}$ & $24.12 \mathrm{~b}$ & $26.28 \mathrm{a}$ & $26.59 \mathrm{a}$ \\
& preharvest and postharvest application & $26.42 \mathrm{~b}$ & $28.68 \mathrm{a}$ & $26.48 \mathrm{a}$ & $23.73 \mathrm{~b}$ & $25.51 \mathrm{~b}$ \\
\hline & & & & & & \\
\hline Hue angle & control & $34.94 \mathrm{a}$ & $31.05 \mathrm{c}$ & $30.81 \mathrm{~b}$ & $30.39 \mathrm{~b}$ & $31.59 \mathrm{~b}$ \\
& preharvest application & $34.59 \mathrm{a}$ & $32.68 \mathrm{~b}$ & $33.18 \mathrm{a}$ & $31.71 \mathrm{~b}$ & $34.25 \mathrm{a}$ \\
& postharvest application & $32.29 \mathrm{~b}$ & $31.58 \mathrm{c}$ & $30.43 \mathrm{~b}$ & $35.64 \mathrm{a}$ & $33.67 \mathrm{a}$ \\
& preharvest and postharvest application & $34.35 \mathrm{a}$ & $33.72 \mathrm{a}$ & $33.73 \mathrm{a}$ & $31.75 \mathrm{~b}$ & $33.34 \mathrm{a}$ \\
\hline
\end{tabular}

\section{Conclusion}

Chitosan, as a semi-permeable coating, can maintain the qualities of the treated fruit and prolong its storage life. It could be considered that chitosan coating slows down the aging process of nectarines by decreasing quality losses nd maintaining membrane integrity. In particular, preharvest chitosan-treated nectarines were firmer and had higher soluble solids content than control ones. Also pre and postharvest application fruits showed high soluble solids content and texture values and the highest titratable acidity. Hence it can be concluded that chitosan in preharvest treatments has the potential to preserve valuable attributes and prolong the shelf-life of postharvest nectarines, presumably of its property to inhibit the ripening and senescence process of postharvest fruits. However, in order to determine the feasibility of using chitosan coatings on a commercial scale, extensive postharvest storage tests are necessary.

\section{Literature cited}

Asgar, A.M., Tengku, M.M., Kamaruzaman, S., \& Yasmeen, S. 2011. Effect of chitosan coatings on the physicochemical characteristics of Eksotika II papaya (Carica papaya L.) fruit during cold storage. Food Chem. 124: 620-626.

Barbosa, L.N., Dias de Mello C. and Rodrigues Monteiro, A. 2011. Influence of temperature and edible coating on the physical and chemical parameters and sensory acceptance of fresh-cut organic carrots. J. Food, 1: 31-36.

Bautista-Baños, S., Hernández-Lauzardo, A.N., Velázquez-del Valle, M.G., HernándezLópez, M., Ait Barka, E., Bosquez-Molina, E. and Wilson, C.L. 2006. Chitosan as a potential natural compound to control pre and postharvest diseases of horticultural commodities. Crop Prot. 25:108-118.

Cè, N., Caciano, P.Z. and Brandelli, N.A. 2012. Antimicrobial activity of chitosan films containing nisin, peptide P34, and natamycin. J. Food 10: 21-26. 
Chiabrando, V. and Giacalone G. 2013. Effect of different coatings in preventing deterioration and preserving the quality of fresh-cut nectarines (cv Big Top). J. Food, DOI:10.1080/19476337.2012.745096.

Devlieghere, F., Vermeulen, A. and Debevere, J. 2004. Chitosan: antimicrobial activity interactions with food components, and applicability as a coating on fruit and vegetables. Food Microbiol. 21: 703-714.

Girardi, C.L., Corrent, A.R., Márcio, L.L., Zanuzo, R., da Costa, T.S., Brackmann, A., Twyman, R.M., Nora, F.R.,Nora, L., Silva, J.A. and Rombald, C.V. Effect of ethylene, intermittent warming and controlled atmosphere on postharvest quality and the occurrence of woolliness in peach (Prunus persica cv. Chiripá) during cold storage. Post. Biol. Technol. 38: 25-33.

Duan, J., Wu, R., Strik, B.C. and Zhao, Y. 2011. Effect of edible coatings on the quality of fresh blueberries (Duke and Elliott) under commercial storage conditions. Post. Biol. Technol. 59: 71-79.

Jiang, Y.M. and Li, Y.B. 2000. Effects of chitosan coating on postharvest life and quality of longan fruit. Food Chem. 73: 139-143.

Jiang, Y., Li, J. and Jiang, W. 2005. Effects of chitosan coating on shelf life of coldstored litchi fruit at ambient temperature. Food Sci. Technol. 38: 757-761Zhou H.W., Lurie S., Lers, A.,

Han, C., Zhao, Y., Leonard, S.W., \& Traber, M.G. 2004. Edible coatings to improve storability and enhance nutritional value of fresh and frozen strawberries (Fragaria ananassa) and raspberries (Rubus idaeus). Post. Biol. Technol. 33, 67- 78.

Kappel, F., Fisher-Fleming, B. and Hogue, E. 1996. Fruit characteristics and sensory attributes of an ideal sweet cherry. HortSci. 31: 443-446.

Khatchitski, A., Sonego, L. and Arie, R.B. 2000 Delayed storage and controlled atmosphere storage of nectarines: two strategies to prevent woolliness. Post. Biol. Technol. 18: 133-141.

$\mathrm{Li}, \mathrm{H}$. and $\mathrm{Yu}, \mathrm{T}$. 2000. Effect of chitosan on incidence of brown rot, quality and physiological attributes of postharvest peach fruit. J. Sci. Food Agric. 81:269-274.

Manganaris, G.A., Vasilakakis, M., Diamantidis, G. and Mignani, I. 2006. Diverse metabolism of cell wall components of melting and non-melting peach genotypes during ripening after harvest or cold storage. J. Sci. Food Agric., 86: 243-250.

Obenland D., Neipp P., Mackey B. and Neven L. 2005. Peach and nectarine quality following treatment with high-temperature forced air combined with controlled atmosphere. HortSci. 40: 1425-1430.

Poovaiah, B.W. and Nukaya, A. 1979. Polygalacturonase and celiulase enzymes in the normal rutgers and mutant in tomato fruits and their relationship to the respiratory climacteric. Plant Physiol. 64: 534-537.

Yonemoto, Y., Higuchi, H. and Kitano Y. 2002. Effects of storage temperature and wax coating on ethylene production, respiration and shelf-life in cherimoya fruit. J. Japan. Soc. Hort. Sci. 71: 643-650. 